\title{
Hijrah and the Articulation of Islamic Identity of Indonesian Millenials on Instagram
}

\author{
TAUFIQUR RAHMAN \\ FRIZKI YULIANTI NURNISYA \\ ADHIANTY NURJANAH \\ Universitias Muhammadiyah Yogyakarta, Indonesia \\ LAILIA HIFZIATI \\ Collegium Civitas, Poland
}

\begin{abstract}
This paper focuses on Indonesian millennial Muslims' experience in using Instagram and how this influenced their hijrah and the articulation of Islamic identity as millennial Muslims. Historically, the term hijrah is traced to the commemoration of the day when the Prophet Muhammad (PBUH) emigrated from Makkah to Madinah. The term is translated as emigration, but then interpreted differently by Muslims in many parts of the world. On the one hand, the term has been used by violent Muslim groups such as ISIS to persuade Muslims to emigrate to the so-called Islamic State. On the other hand, the young generation of Muslims use it to declare a spiritual emigration and pursue a better life. This paper asks how millennial Muslims in Indonesia interpret the term hijrah and how they articulate the idea of hijrah and their Islamic identity into their activities on Instagram. The study employs critical discourse analysis as its primary and virtual ethnography as a secondary research method to reveal the articulation of the term hijrah in social media by millennial Muslims in Indonesia. This study indicates that the spirit of hijrah in Instagram by millennial Muslims is more about a spiritual journey rather than a political movement. The hijrah phenomenon on Instagram was also celebrated differently by informants, considering the cultural background, gender, parental education, living environment, and education, which affected the migration process differently.
\end{abstract}

Keywords: Hijrah, Islam, identity, millennial, Instagram.

\section{INTRODUCTION}

Social media has offered a new opportunity for people to share information more easily from time to time. Social media not only provides a new space for information sharing, but also creates a unique culture developed in cyberspace, which is commonly termed as cyberculture (Greenberg, 2008). This new outlet's promised power of interactivity has attracted many individuals and many different groups of people to articulate their identities and disseminate ideas, including those with religious messages.

Over the last several years, Instagram became increasingly preferred as a choice of social media platform by Indonesian millennials. In 2019, Indonesia was the fourth most prominent Instagram user after Brazil, India, and the United States. The country was considered having the biggest Instagram community in Asia and the Pacific (Statista, 2019). Instagram is becoming the most popular social media platform for the millennial generation because of its simplicity, efficiency, and the availability of interesting gradually updated features. 
Millennials are not only described as digital natives, but also as "the most narcissistic generation" (Bergman, Fearrington, Davenport \& Bergman, 2011). The combination of selfpromotion and familiarity with technology makes millennials adept at crafting their online world identity. On Instagram, the main attraction is its focus on visual messages especially photos and videos. This visual power helps to form a new self-definition and offer selfinvention; each person has unlimited ability to create themselves in the cyber-world. (Nasrullah, 2011). Furthermore, every individual has three essential powers; one of them is identity fluidity. This means that the process of constructing virtual and non-virtual identity does not always produce the same identity (Jordan, 1999). For instance, Indonesian Muslim millennials have a new perspective that religious identity can also be shown in public spheres, not only private spiritual dominance (Pahdepie, 2018).

Religion offers a more meaningful life for the millennials in Indonesia (Heriyanto, 2018). Hijrah has become one of the most popular issues among young generations of Muslims in Indonesia because many millennials think that religion can help them become better and happier people. A survey conducted by Varkey Foundation shows that $93 \%$ of young Indonesians believe that religion is a key to happiness (Heriyanto, 2018). The millennial generation can have seemingly unlimited access to the world out there thanks to the advance of technology at their fingertips (Nawi, Zakaria, Hashim, Mahalle \& Ren, 2020). However, they need religion as a compass for and in their lives. Mark Wildes, the Director of the Manhattan Jewish Experience argues that 'the click of the keyboard and the tap of a phone app may give us access to the world, but only religion can provide a portal to the sublime' (Wildes, 2017).

Indonesian millennials can be divided into two groups, junior millennials; those who were born from 1992-1999 (21-28 years old) and senior millennials; those who were born from 1984-1991 (29-36 years old) (IDN Research Institute, 2020). According to Noormega (2019), a social psychologist from University of Indonesia, both groups will experience uncertainty in the process of finding their identities. Religion and hijrah movement help give those identity seekers the feeling of security. It is becoming something to hold on to for them. Hijrah itself is a form of identity transformation that is becoming a trend among millennials in which influencers are spreading, through social media (IDN Research Institute, 2020). Likewise, Hall (1990) said that there are two kinds of identities, (1) identity as being (which offers a sense of unity and commonality) and (2) identity of becoming (or a process of identification, which shows the discontinuity in our identity formation).

A recent research conducted by IDN found that hijrah has become a growing trend among Indonesian Muslim millennials (IDN Research Institute, 2020). In addition, most of the respondents in the research agreed that some hijrah behaviours were mostly about their daily lifestyle changes. Another study by Suraya and Mulyana (2020) indicates that the frequency of digital media usage by Indonesian youth, especially among high school students, only contributes to radical attitudes.

In light of this, Instagram can be seen as a platform which provides these young people an opportunity to become part of the hijrah community and indirectly form their identity. Research on other social media platforms such as Facebook has demonstrated social media's potential as a medium for the construction of various identities (Jamilah \& Mohd, 2020). Therefore, it is possible to see how the society express their hijrah and articulate their Muslim identity online, by analysing how they use Instagram as a tool.

Previous studies related to the idea of hijrah on the Internet mainly investigate a specific online group or community which uses the term hijrah as the primary identity of their group (See, Prasanti \& Indriani, 2019; Zahara, Wildan \& Komariah, 2020). This paper 
investigates the interpretation of the term hijrah explicitly by Muslim millennials in Indonesia and analyses how they articulate the practice of hijrah and express their Islamic identity in social media, especially on Instagram.

\section{LITERATURE REVIEW}

In 1999, Eickelman and Anderson edited a compilation on the usage of Internet in the Muslim world. In the preface of the book, they argue that the Internet has a significant role in expanding Muslim public spheres and has become a new marketplace for Islamic ideas, identities, and discourses (Eickelman \& Anderson, 1999). Eickelman and Anderson's argument provides a basic premise for this study concerning the increasing use of the Internet in articulating religious ideas in predominantly Muslim countries, including Indonesia.

Several studies have also explored the construction of Islamic identity through the Internet. For instance, Rogan (2006) investigates the Internet's use as an instrument for a global jihad movement by Islamic terrorist groups. Rogan contends that the Internet has become an essential medium for global jihadists to disseminate their propaganda by using the combination of written and audio-visual materials. More recently, Chaniago (2020) investigates the use of social media to articulate the identity of 'metal hijabs' or women who wear hijab and love metal music subculture in Indonesia. Turner (2007) and Campbell (2007) investigate how the concept of authority is employed on the Internet for religious purposes. Turner argues that authority, traditionally obtained by the use of print media has been challenged by new media, especially in many diasporic Muslim communities. Campbell asserts that although the Internet has become a new source for religious authority in Islam, the conventional 'offline' religious rules will remain influential in traditional hierarchical Muslim communities. Turner and Campbell's studies suggest that the Internet may play an increasingly important role in the formation and contestation of Islamic religious authority in contemporary Muslim societies.

More recent discussions highlight the implication of the Internet's multimodal and convivial characteristics as an instrument for Islamic identity formation and representation. Lim (2005) employed the Internet as a social tool in a conceptual framework for her PhD project titled 'Archipelago online: The Internet and political activism in Indonesia'. She concludes that;

By being convivial, the most critical functions of the Internet in facilitating and supporting political activism have been the sharing of otherwise hard to find information and the self-organising of resistance that the information has made possible (p. 180).

Ameripour, Nicholson and Newman (2009) investigate the contribution of the Internet's social characteristics to societal conviviality in Iran by analysing blogs created by Muslim feminists and a campaign called 'Stop Stoning Forever'. This study concludes that the campaigns have attracted public interest in the virtual world, but not in Iranian society's actual public spaces. The research conducted by both Lim and Ameripour and colleagues supports the value of friendliness in analysing different types of social activism in cyberspace. Also, Sands (2010) investigates the implication of the Internet's multimodal characteristic for Muslim identity formation and representation. Sands contends that the Internet has facilitated the emergence of alternative representations of Muslim identity because of this 
new media's capability to encourage more active participation among more interconnected users. According to Sands, the expression of these alternative identities is supported by the availability of multiple linkages and a mix of written texts, images and sounds on the online spaces. Sands further argues that the Internet's multimodality has facilitated 'alternative forms of engagements, and alternative social and political arrangements' through the potential use of 'multiple linkages' and 'the particular vernacular spoken in this medium' (Sands, 2010, p. 154).

The studies mentioned above demonstrate varying perspectives on the Internet's role in constructing Islamic identities in contemporary Muslim societies depending on the local social and political condition. Several studies suggest that in many traditional hierarchical Muslim communities, the Internet's role is limited (see Campbel, 2007; Ameripour, Nicholson \& Newman, 2009). However, several other studies suggest that globally, the Internet plays a significant role in transforming Islamic religious authority (see Eickelman \& Anderson, 1999; Turner, 2007). It certainly appears plausible where the Internet is available. The trans-national authority is now challenging the old traditional authority of local imam or Islamic clerics with the availability of direct connection with Islamic clerics and the abundance of religious learning resources from the Middle East, the United States, the United Kingdom or anywhere else in the world (Mandaville, 2001). An internet survey of young Muslims in Australia, Indonesia, Malaysia and Singapore shows that most respondents use the Internet to find alternative sources of information about Islam that they cannot find in other media (Bahfen, 2008). This transformation of authority is possible in Islam because the religious power in contemporary Muslim societies is achieved more by widespread recognition and support than a hierarchical system of authority (Turner, 2007). The non-hierarchical nature of the Internet goes hand in hand with the non-hierarchical nature of Islamic rule (within the majority of Muslim communities) in constructing Islamic identity in contemporary Muslim societies including Indonesia as the most prominent Muslim country in the world.

\section{RESEARCH METHOD}

This research combines the use of critical discourse analysis and online ethnography as the research method. Specifically, the socio-cognitive approach of Critical Discourse Analysis (CDA) developed by Van Djik (2001) is utilised in this research. This approach focuses on sociocognitive structures in mediating texts and society, and the complexities of the relationship between discourse structure and social structures. Several elements of discourse are analysed including semantic macrostructures and schematic structures of the text (topics, propositional structures), local meaning(s) (choice of vocabulary, specific culturally conditioned arguments), socio-cultural context, 'event models' (the context and facts represented in the text), and the relationship between the text and its broader social context. In employing this approach, the researchers analyse several features of the Instagram posts, including texts, pictures, videos, and (where possible) the source of information quoted in the posts.

Online or virtual ethnography is also used as a secondary research method in addition to critical discourse analysis. Hine (2000) recommends the combination of the use of virtual ethnography and discourse analysis in observing online interactions. Ethnography can be defined as a qualitative research method, which intends to provide a detailed, in-depth description of everyday life and practice. Ethnographic research aims to give the researcher 'access to the way that people's lives are meaningful to them on their own terms' (Machin, 2002). Virtual ethnography has emerged as a new tool in analysing the dynamics of virtual communities by adapting the use of common participant-observation ethnographic 
procedures in the face to face interaction to the virtual interaction in cyberspace (Kozinets, 2010). This research's data collection methods include online observation, online interview, and capturing chat-logs, screenshots, video or audio.

Eight participants were chosen as informants and interviewed for this research. All informants were selected based on the following criteria: 1) The participant can be seen as a member of the Millennials generation; 2) The participant is an active user of Instagram and has a minimum 500 followers; 3 ) The participant has followed Islamic accounts on Instagram for more than two years. An equal number of male and female participants were selected in this research.

\section{Interpreting Hijrah}

\section{RESULTS}

The term hijrah in the Indonesian language dictionary is translated as 'emigrate' or 'move away temporarily from one place to a better place for a specific reason such as safety or pursuing a better life'. The term's origin was used to explain the physical migration of the Prophet Muhammad from Mecca to Medina in AD 622 and the migration of a group of Muslims from Mecca to Abyssinia in AD 615-622 (Masud, 1990). In Many cases, hijrah is associated with the migration from the land of infidels to Islam's land. However, in the Sufi's tradition, hijrah is defined more as a spiritual emigration, not a physical movement.

Many Instagram users use the word hijrah in their accounts or use hashtag hijrah in their posts on Instagram. Several definitions of hijrah were found in their postings. For instance, a description of hijrah was found in a post from @pemudahijrah as one of the most popular accounts discussing hijrah. The post is an invitation for a religious gathering with the Pemuda Hijrah movement founder, Hanan Attaqi (see Figure 1 below). A short description accompanies the invitation for hijrah. The story contains a definition that 'hijrah means moving away from a place to another place' [berpindah dari satu tempat ke tempat yang lain]. The description is supported by a definition of hijrah taken from a hadith that the essence of hijrah is avoiding all that are forbidden by Allah and the Prophet Muhammad. Both the outward which is visible and the inner (matters of the heart) [hijrah yang hakiki sesungguhnya bermakna meninggalkan segala yang dilarang oleh Allah dan Rasul-nya. Baik yang lahir (terlihat/nyata/riil) maupun yang batin (tidak nyata, perkara hati, ghaib)].
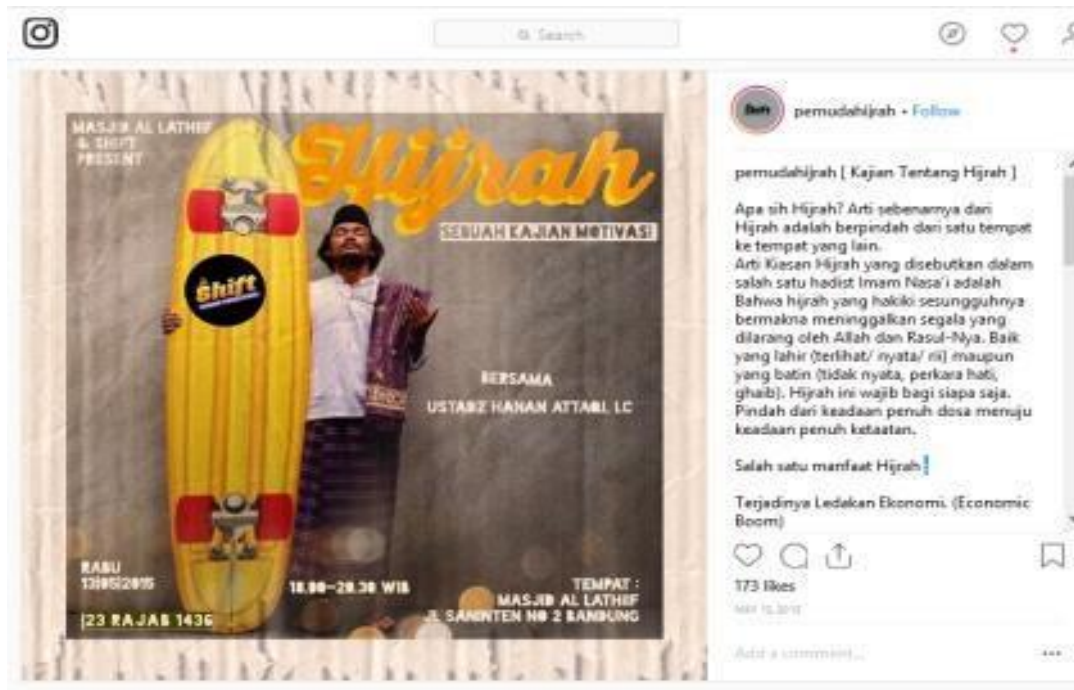

Figure 1: A post related to a definition of hijrah 
Another post that quotes a definition of hijrah is by Adi Hidayat, another Muslim preacher popular among the young generation of Muslims in Indonesia (see Figure 2). This post shows a video which contains an excerpt of Adi Hidayat's speech about the meaning of hijrah. In this speech, Adi Hidayat says that the practice of hijrah is not articulated by becoming a member of an organisation or a member of a group. Hijrah also cannot be done only by changing one's appearance. He further argues that the easy way to do hijrah is to become a better person in Allah's view.

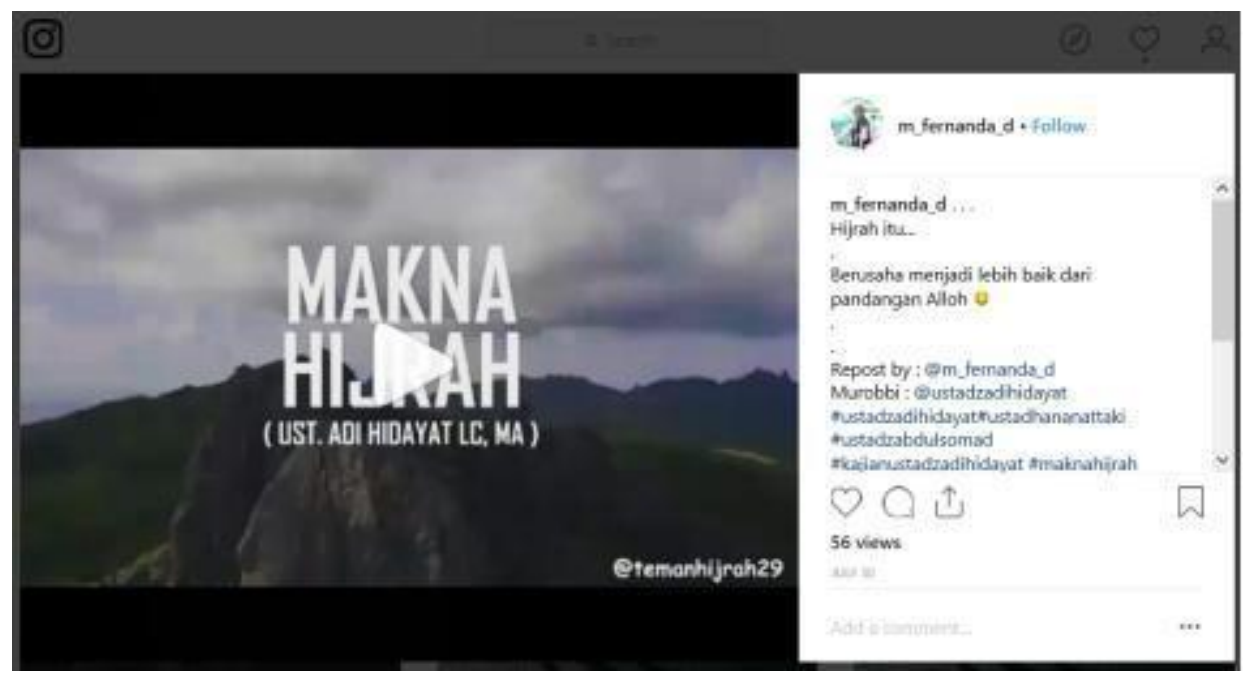

Figure 2: A short video about the meaning of hijrah

Hence, for many Indonesian Muslim millenials, hijrah is understood more like a spiritual journey to become a better person. According to one of the informants, FA;

"Hijrah is a form of self-improvement that helps one get closer to God, avoiding the forbidden things and performing Allah's command".

Another opinion was mentioned by EL, who said that;

"Hijrah means changing bad habits to the good and transforming from a fasik to a real Muslim."

An informant, $A G$, says;

"Hijrah is leaving things that are to Allah's dislike and moving toward things that are to Allah's like and have faith in that. The simple application is that we hate what Allah and the Prophet have forbidden and appreciate what pleases Allah and the Prophet (...) but learning the religion according to the Quran and the hadith."

Another informant, AS, believes that hijrah is an individual's process to leave what Allah dislikes and move towards what Allah loves. The effort can be made by obeying Allah's commands, avoiding what Allah forbids while becoming a better person. Hijrah is also a dynamic process with the ultimate goal to obtain the pleasure of Allah. 
Our research project's informants mostly echoed the description of hijrah the way the preacher they follow on Instagram would do, such as referring to Hanan Attaqi and Adi Hidayat. A similarity of opinions found in this research confirms the power of young and famous preachers as new interpreters of Islam and their ability to influence their followers on social media.

\section{The Source of Religious Authority}

All of our informants tend to rely on Instagram if they want to learn about Islam. From the Instagram account of EL, we can see that he/she followed 91 Islamic accounts from various countries, yet $90 \%$ of these accounts are from Indonesia. The Instagram account of AS followed 39 Islamic accounts, the account of FA followed 25 Islamic accounts, and AG's account followed 9 Islamic accounts. All participants followed @pemudahijrah as the most popular hijrah related account on Instagram so far, with more than 1.4 million followers. This phenomenon indicates the change in the practice of religious authority in Indonesia which previously relied on the authority of traditional Islamic clerics in the mosque or traditional school and is currently challenged by the arrival of new interpreters of Islam. This phenomenon is possible because the religious authority in contemporary Muslim society is attained more by widespread recognition rather than a hierarchical system of authority (Turner, 2007).

Social media is designed as a user friendly and efficient platform. Many religious contents are usually complex and challenging to understand, often simplified and condensed, because Instagram can only accommodate videos with a duration of 1 minute or less. AG, one of the informants, says that;

"knowledge can be easily comprehended and understood from a simple thing.

I am grateful that many ustadz share their knowledge through social media."

According to AG, his favourite account is @yufidtv, @shafiqriezabasalamahofficial, @muhammadnuzulzikri, and @ustadbawazir.

Hijrah in social media can be seen as a modern way of Islamic preaching. The contents are often also suitable for beginners. Another informant, EL, argues that hijrah in social media is good because it follows the trend. Current generations usually are busier in and on social media rather than being in the mosque. She further argues that the Islamic accounts help her understand religion better, and Islamic accounts in Instagram can also bring millennial Muslims closer to their faith. Another informant, FA, admits that he likes Islamic accounts with many quotes from the Quran and hadith.

All informants do not identify with a specific Muslim group or organisation, although they have one or several favourite accounts. For example, AS, a male informant, argues that he does not have any favourite account. He likes any message which he finds useful and does not bring him into conflict. This statement supports the result of the Pew Research Center's survey that millennials have become less attached to political and religious institutions (Pew Research Center, 2014).

Instagram accounts such as @pemudahijrah contain many types of Islamic messages such as quotes from Quran and Hadith, video excerpts from popular Muslim preachers' speeches which usually offers an invitation to attend offline religious gatherings. The Pemuda Hijrah account was an idea that came from a group of Muslim youth who regularly attended 
religious meetings at Al-Lathiif Mosque in Bandung West Java. They have had many problems in their life and decided to start hijrah and persuade others to join. Under the banner of @ pemudahijrah, they try to develop suitable religious youth approaches because their targets are the young generation of Muslims. They initially started with issues closer to the challenges they met in their everyday settings, such as finding a life partner and using a more informal language and title in promoting their religious gatherings. They also designed posters for such meetings using a more stylish design such as inserting a picture of a young Indonesian skateboarder as an icon to attract young millennial Muslims' attention.

Various themes can be found in these hijrah accounts. If the @pemudahijrah account contains a more general appeal to do hijrah, another account, namely @kembalihijrah, discusses more specifically how to become an ideal wife or husband according to Islam. For instance, on this account, one could find a post that quotes a statement from Syafiq Riza Basalamah, stating that women should go to work, but her work is not for money. Instead, her career is to nurture future generations, to nurture future leaders and Muslim scholars (see Figure 3). On the account, there is another post referring to the profile of an ideal husband. According to @kembalihijrah, a perfect husband is a husband who can understand how challenging domestic work is, which his wife has to do at home (see Figure 4). The two posts mentioned above indicate that a good woman should stay at home and educate her children whilst doing domestic jobs.

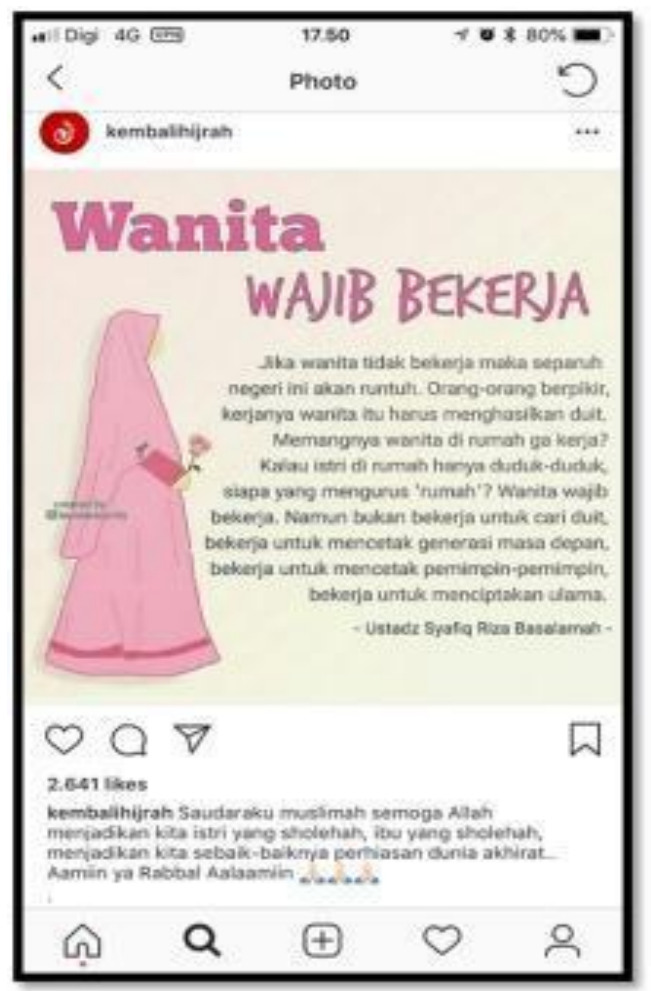

Figure 3: A post about the responsibility of a wife 


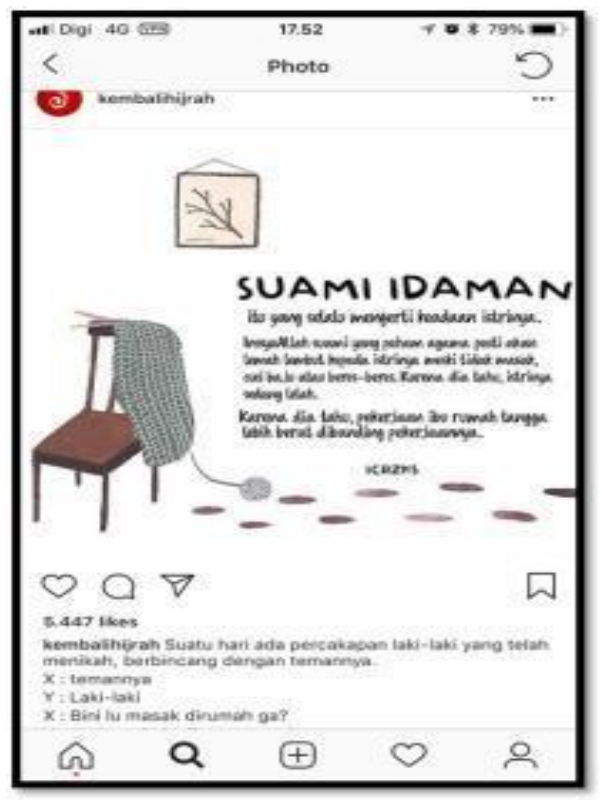

Figure 4: A post about an ideal husband

The concept of hijrah in @kembalihijrah mainly relates to guidance on how to maintain relationships between a husband and wife. Examples of the two posts mentioned above indicate the owner of @kembalihijrah believes that the ideal position of a wife is in the domestic sector. The hijrah of a woman, according to @kembalihijrah, is foremost by staying at home, to educate her children and do household work. Another post in @kembalihijrah shows a similar imbalanced perspective on the relationship between man and woman and endows the hard work with seemingly less appreciation. In this particular post, @kembalihijrah quoted a statement "when a wife is complaining about her feelings and her husband always asks her to be patient, while her husband feels more than what his wife complaining about" (see Figure 5).

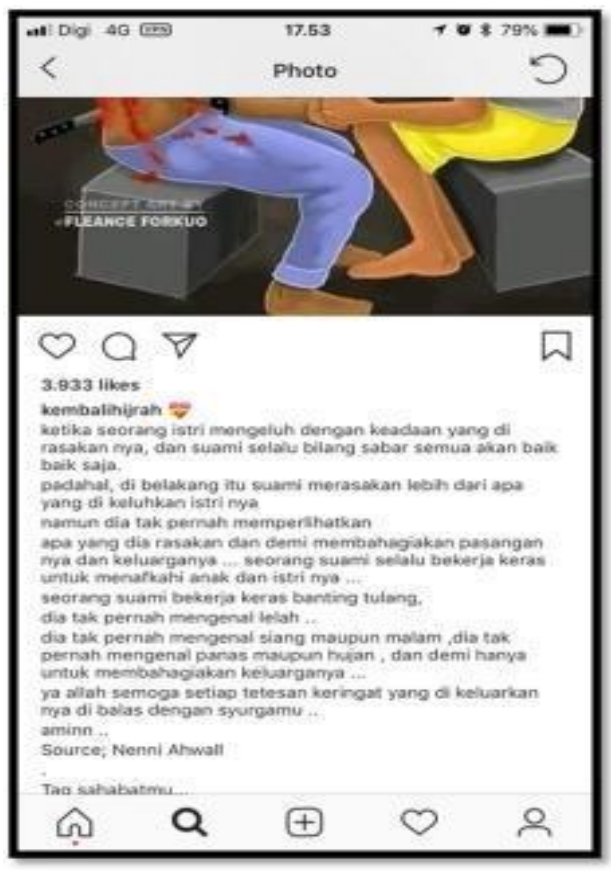

Figure 5: A post about husband and wife relations 
Following an Instagram account means that an individual is interested in the account's posts. As stated earlier, the higher an individual's interest and needs for Islamic content, the greater the individual's intensity in accessing these accounts. Hijrah on social media requires serious consistency and effort. To improve themselves, people who are doing hijrah will follow relevant accounts that can assist them in studying religion.

All informants follow various types of Islamic accounts on social media because each account provides different information. For example, @gerakanindonesiatanpapacaran content focuses on the dangers of dating. Meanwhile, @rumaysho.com focuses on providing information in the form of a hadith discussion or a brief explanation of jurisprudence. Informants suggest that Instagram is more effective because previously, the contents were long and heavy. Nowadays, it has changed to a shorter and more exciting way of delivery because Instagram's video duration was less than 1 minute.

The content shared by Islamic accounts is brief and reliable, but still provides positive feedback from followers. The content becomes very easy to understand for those who are just learning about Islam, as revealed by the informant AG;

"Because that knowledge will be open and more understandable and delivered in a simple manner. And I'm grateful we have a lot of clerics who share knowledge through social media".

Informant OJ said that the interest in following Islamic accounts is because of the ease of learning provided, such as accounts @pemudaberhijrah.

"I like the way Ustadz Hanan Attaki lectures because the way he explains is straightforward and easy to understand for beginners".

Meanwhile, IY itself follows an Islamic account because he has reaped great benefits after two years have passed.

At the beginning of the hijrah, all informants admitted that they follow information or religious knowledge from various accounts. They choose the account according to their preference; the account would be followed regularly, either through Instagram stories or Instagram feeds. But apparently, the selection process of Islamic accounts continues to be carried out by each user. As a result, some accounts were finally unfollowed if it was felt to be out of line with the informants' needs. For instance, informant AY and EL who had previously followed various accounts that discussed marriage content, then stopped following these accounts for personal reasons. EL said:

"I used to follow many marriage accounts, but over time the contents were lame and boring."

Whereas AY revealed that :

"Some accounts did not update it's content, they put the same sentences. The only difference is the design and graphics. So, lately, I unfollowed it". 
Informant EL himself prefers to follow accounts that actively share prayers, explanations of monotheism, repentance, and jurisprudence. According to him, accounts with such information can be applied directly and answer daily questions regarding how to behave and how to conduct good human relations. The four male informants also precisely followed Islamic accounts that focused on the discussion of hadith, interpretations of Quran and Arabic lessons.

\section{Articulating Islamic Identity}

Instagram has an algorithmic feature so that the content provided is relevant to users' interests (Mosseri, 2021). On Instagram itself, there are three main factors in determining the content seen in Instagram feeds, including interest, timeliness, and relationship. The content's ranking is based on three additional criteria: frequency, following, and usage (Constine, 2018). This is what causes feeds on each Instagram users' account to always be different, and very personal depending on user needs. Thus, this bubble effect causes its users to be in the same concern and issue. It can be concluded that the identity formed by Instagram does not happen instantly. Still, it is a long process and cannot be separated from someone's intensity using Instagram, the content that he likes, and the account he follows. There are several ways participants articulate their Islamic Identity on Instagram:

\section{a. The Religious Instagram Biography (Instagram Bio)}

The interesting thing about the millennials who have done hijrah is that most of them showcase their religious behaviour through the biography of Instagram. The biography does not only function as a means for giving out ordinary information, it also acts as a way to get to know the account owner. Instagram bio itself is an essential part of an Instagram profile. When we meet someone personally, the external appearance and behaviour influences the first impression. Similarly, Instagram bio is an integral part of the first impression on Instagram.

Based on the observations, each account has its uniqueness in using their favourite quotes or verse fragments in their Instagram bio. This quote can be in the form of a motto, aphorisms, vision-mission, or self-reminder. EL uses a fragment of chapter At-Tahrim verse no. 6 in his Instagram bio. In addition, EL also added an Arabic quote that means "Who is patient then he who gets it."

Meanwhile, FA chose to use an Arabic quote rather than a fragment of Qur'an, which means, "if you want to see how you are in the future, then look at your situation in the present." US only uses an Arabic quote as an opening for his Instagram bio, meaning "there is nothing else in my heart except Allah." OJ chose to use an Arabic aphorism namely "Hasbi Rabbi Jalallah, Mafi Qolbi Ghoirullah", AY uses the oneness of the God (tauhid) declaration sentence as his Instagram bio, i.e. Laailaahillallah, Muhammadarrasulullah, and AD quotes a fragment from Al-Imran verse 139 which can be translated as "So do not weaken and do not grieve, and you will be superior if you are (true) believers."

The different types of quotations or verses of the Qur'an that are diverse, but this bio description has the same purpose; namely, the account owner wants to give information to someone about the identity they belong to. This can be seen from the different languages used, and the types of writing used, some of which use Latin letters, Arabic words, and some of them using English, but still have Islamic elements. By applying Islamic words, someone who reads the biography can understand that the account owner has a particular interest in Islamic matters. 


\section{b. The Attitude of Photo and Video Sharing After Hijrah}

The results show fundamental differences in how photos are uploaded before and after deciding on hijrah. Previously, participants uploaded pictures freely with any poses, and now they thought more before uploading photos. Some informants use their account to do Islamic preaching ( $\left.d a^{\prime} w a h\right)$ and significantly limit their photos on Instagram.

Interestingly, there were fewer photos of female informants than male informants. Also, male informants did not use emoticons or stickers to cover parts of their faces. Many female informants use blur, emoticons, or stickers to protect their faces. Not only that, the photo poses uploaded by female informants are mostly photos that do not show their faces.

Although there are differences in how they uploaded photos of themselves, it turns out that all informants have similarities in sharing Islamic content in their accounts.

\section{c. Instastory, Highlight, and Archiving Islamic Contents}

In addition to the feeds and biography features, Instagram users can also set Instastory, highlight, and archive posts scattered on Instagram, all of which are arranged based on each user's needs and personality. Instastory is equipped with various emoticons, moving images, and filters that allow users to be freer to create and express themselves. While highlight is an extension of Instastory, this highlight feature is very popular with millennials, because this feature allows users to store prior Instastory which have been shared. Highlights are a new space on user's profiles where stories that have previously been shared can be added, allowing them to present their stories for more than 24 hours. To show their religious messages, informants usually use Instastory. Every day, informants update their Instastory at least once and sometimes up to five contents a day.

As with the highlight feature, the archive feature was introduced to the public in 2016. This saved feature is the right tool for those who need an application to store new ideas. Furthermore, they can save photos from the accounts they follow, and the accounts they do not follow. This feature is the same as the Pinterest application where users can save files that they like and make them easier to find.

The use of archive features is useful because users can save sequential files based on the desired folder. For example, when the informants are interested in Islamic accounts that provide information about daily prayers, tauhid, how to work, discuss fiqh, it can be stored in a particular folder on Instagram by using the 'saved' feature to save the file. Likewise, suppose in the future, the informants want to focus on specific issues such as marriage,. in this case, it is easy for them to prepare a separate folder so that later it can be easier to find this unique content.

Muslim millennials use the various Instagram features to construct their Muslim identity on Instagram social media. They put their own bio, filter photos, upload, highlight some stories and save data relating to religious studies, interpretations of the Qur'an, hadith, or compilation of lectures from their favourite preachers.

\section{d. The Islamic Religious Caption}

All informants have also written captions on Instagram to show their opinions, share stories about the process or wisdom gained that day. From the data analysis, researchers concluded that the form of hijrah as identity is reflected in captions for various photos. 
From the informants' uploaded photos and captions, some use personal photos and add captions that are personal opinions. Some use images taken from the Internet with captions from the Qur'an and hadith, or thoughts of others. Although using different ways, all content have a similarity, namely devotion to Allah and the Prophet Muhammad p.b.u.h.

\section{Hijrah in the Virtual World vs Hijrah in Real Life}

Informants have different perspectives related to the phenomenon of hijrah on social media. The necessary thing about hijrah on social media or real life is how to put right the intention that hijrah is a purifier with the purpose to only worship Allah. They also feel that the hijrah movement on social media is not a temporary move, but a continuous behaviour because the most challenging thing after a good change is consistency.

One of the informants, EL said that hijrah on social media does not necessarily occur directly in real life; there is a continuous process. EL realises the Islamic content he gets from following Islamic accounts is not enough to give him an in-depth understanding of a topic, so he slowly tries to gain more knowledge through self-studies and in this case, follows a mosque's Instagram account. EL thinks that the process of hijrah is a long journey which peaked when he finally decided to delete his photos and focus on sharing Islamic content.

Another informant, US, believes that the articulation of hijrah on social media must also be practised daily but it is also the most challenging aspect. He said that hijrah requires great intentions and excellent support by following Islamic accounts, accounts of a public figure who did hijrah or starting to follow accounts that provide references to Islamic studies.

Informants $A D$ and $A G$ agreed that the understanding of religion through the Internet is minimal. According to $A G$, the problem of the hereafter must be from the best source. He said;

"Alhamdulillah, I am diligently taking part in the 2-3 weeks study at the Lawatta Mosque, and the Islamic Center of Mataram, this is to support my understanding and deepen the knowledge that I have gained in social media."

Meanwhile, AD regularly studies in mosques in Bandung. AY added that he disagrees with the online term of hijrah. AY said that online hijrah exists from those who absorb Islamic information only through charts or social media, only in the form of short quotes or videos. At the same time, they do not merely learn about Islam on Instagram but also through local clerics who have qualified knowledge on Islam.

\section{DISCUSSION}

Identity refers to the reflection of oneself and others' perceptions of us as a different individual in behaving and believing. Instagram provides a virtual medium for Muslim millennials to articulate their online identity through Instagram features. The Instagram features reflect the users' reflection to provide their followers with their online identities as a part of the hijrah movement.

Instagram has an impact not only on the economy and politics, but also on the online culture. This application has different characteristics and focuses on visual signs as the main attraction. Instagram provides its users with distinct online communities and pieces of information worldwide driven by artificial intelligence based on user generated content. In the beginning, the hijrah phenomenon on Instagram was only a place to share photos and videos. 
However, the evolution of Instagram features made the users, especially millennials as online native, use their accounts to build their online identities, and participate in a combination of offline-online Islamic movements with Islamic communities they followed on Instagram.

Instagram provides a convenient space for Muslim millennials. First, on Instagram, the Muslim millennials have a place to connect with other peers who belong to the same movement, for example by sharing Islamic content on their instastories. By sharing daily Friday reminders to read a specific chapter of Qur'an or daily prayers from one of the famous Islamic accounts gives Muslim millennials a sense of unity from their followers who follow the same Islamic accounts. Secondly, the hijrah movement on Instagram has become a place for Muslim millennials to show their current identity and journey to find the truth. They also offer how they implement Islamic knowledge in their offline and online activities, such as limiting content related to themselves while increasing content about Islamic reminders.

The Hijrah of Muslim millennials on Instagram is a new revolution of Islamic movement embedded in the virtual world. The creativity involved by millennials as digital natives have allowed them to articulate their thoughts differently from other generations. In particular, features available on Instagram gives them opportunities to express themselves more broadly and interact with distinct Islamic online and offline movements locally and internationally. For millennial Muslims, Instagram provides them with a place to find religious teaching by following Islamic preachers online and expressing those identities through Instagram features by showing support, following, saving, and reposting other Islamic accounts.

Furthermore, it is interesting to note that hijrah on Instagram affects the users offline and online and changes their attitude online and offline. In the past, hijrah can only be observed if the individual changes their physical appearance. But today, it can be articulated virtually by using Instagram features to confirm themselves through the elements, such as Instagram stories, Instagram bio, and highlights.

\section{CONCLUSION}

The spirit of hijrah in Instagram by millennial Muslims is more of a spiritual journey rather than a political movement. Articulation of hijrah on Instagram can mainly be seen from the use of Instagram bio, highlights, and saved Instagram features which defined the millennial Muslims' needs in shaping their desired identity. Although it cannot be denied that Instagram is a medium which allows people to make a first impression, it must be pointed out that it is not the only measure of personality and individuality.

The hijrah phenomenon on Instagram was portrayed differently by informants, considering the cultural background, gender, parental education, living environment, and education, which affected the process they went through. The common action that they take is by closing their old accounts and opening a new account to show the actual manifestation of hijrah. Also, those emigrating individuals have tried to apply the knowledge that has been obtained online and offline to open a different self-identity sheet by maximising Instagram features as an extension of self-image, and showing the perceived truly Islamic identity to their followers. Therefore, for many millennial Muslims, hijrah is a process of becoming a better person, no matter who they are. 


\section{BIODATA}

Taufiqur Rahman is a lecturer in the Department of Communication Universitas Muhammadiyah Yogyakarta Indonesia. Email: taufiqurrahman@umy.ac.id

Frizki Yulianti Nurnisya is a lecturer in the Department of Communication Universitas Muhammadiyah Yogyakarta Indonesia. Email: frizkinurnisya@gmail.com

Adhianty Nurjanah is a lecturer in the Department of Communication Universitas Muhammadiyah Yogyakarta Indonesia. Email: adhianty@umy.ac.id

Lailia Hifziati is a postgraduate student at Collegium Civitas Poland. Email: alhifzi.co@gmail.com 


\section{REFERENCES}

Ameripour, A., Nicholson, B., \& Newman, M. (2009). Internet usage under authoritarian regimes: Conviviality, community, blogging and online campaigning in Iran. In R. Heeks (Ed.), Digital development working papers (di-wp43). University of Manchester. https://www.gdi.manchester.ac.uk/research/publications/di/di-wp43/

Bahfen, N. (2008). Online Islamic identity and community in Australia and three neighbouring countries [Doctor of Philosophy thesis, The University of Technology Sydney]. OPUS at UTS. http://hdl.handle.net/10453/20280

Bergman, S. M., Fearrington, M. E., Davenport, S. W., \& Bergman, J. Z. (2011). Millennials, narcissism, and social networking: What narcissists do on social networking sites and why. Personality and Individual Differences, 50, 706-7011.

Campbell, H. (2007). Who's got the power? Religious authority and the Internet. Journal of Computer Mediated Communication, 12.

Chaniago, R. H. (2020). Media sosial, alat komunikasi alternatif suara wanita: Satu kajian mengenai peranan wanita berhijab dalam sub-budaya muzik metal di Indonesia. Jurnal Komunikasi: Malaysian Journal of Communication, 36(2), 33-51. https://doi.org/10.17576/JKMJC-2020-3602-03

Constine, J. (2018). Instagram hits 1 billion monthly users, up from 800 in September. Tech Crunch. https://techcrunch.com/2018/06/20/instagram-1-billion-users/

Eickelman, D. F., \& Anderson, J. W. (1999). New media in the Muslim world: The emerging public sphere. Bloomington: Indiana University Press.

Greenberg, G. S. (2008) CMC and the nature of human/ machine interface. In S. Kelsey \& K. St. Aman (Eds), Handbook of research on computer mediated communication. New York: Information Science Reference.

Hall, S. (1990). Identity: Community, culture, difference (Ed. by Jonathan Rutherford, pp. 274295). London: Lawrence \& Wishart.

Heriyanto, D. (2018, June 2018). Indonesian youths say religion key to happiness, bucking global trend (News: National). The Jakarta Post. Retrieved from https://www.thejakartapost.com/news/2018/06/01/indonesian-youths-say-religionkey-to-happiness-bucking-global-trend.html

Hine, C. (2000). Virtual ethnography. London: Sage Publications.

IDN Research Institute. (2020). Indonesia millennial report 2020. https://cdn.idntimes.com/content-documents/Indonesia-millennial-report-2020-byIDN-Research-Institute.pdf

Jordan, T. (1999). Cyberpower, The culture and politics of cyberspace and the Internet. London: Routledge.

Kozinets, R.V. (2010). Netnography: Doing ethnographic research online. Los Angeles: Sage.

Lim, M. (2005). @rchipelago online: The Internet and political activism in Indonesia [Unpublished PhD dissertation, The University of Twente]. University of Twente Research Information. https://research.utwente.nl/en/publications/rchipelago-online Machin, D. (2002). Ethnographic research for media studies. London: Arnold.

Mosseri, A. (2021) Shedding more light on how instagram works. Instagram. https://about.instagram.com/blog/announcements/shedding-more-light-on-howinstagram-works

Jamilah Maliki, \& Mohd Nor Shahizan Ali. (2020). Pengaruh faktor pengetahuan terhadap konstruksi identiti dalam talian menerusi penggunaan Facebook. Jurnal Komunikasi: Malaysian Journal of Communication, 36(3), 176-194. https://doi.org/gk3b 
Mandaville, M. (2001). Transnational Muslim politics: Reimagining the umma. London: Routledge.

Masud, M. K. (1990). The obligation to migrate: The doctrine of hijra in Islamic law. In D. F. Eickelman \& J. Piscatori (Eds.), Muslim travellers: Pilgrimage, migration, and the religious imagination. London: Routledge.

Nasrullah. (2011). Konstruksi identitas Muslim di media baru. KOMUNIKA, 5(2), 221-234.

Nawi, A., Zakaria, G. A. N., Hashim, N., Mahalle, S., \& Ren, C. C. (2020). The needs of Islamic digital resources in Polytechnic Brunei Darussalam: A preliminary study. International Journal of Instruction, 13(1), 225-234. https://doi.org/10.29333/iji.2020.13115a

Noormega, R. (2019, Oct 7). Hijrah: The pursuit of identity for milennials. IDN Research Institute. https://medium.com/idn-research-institute/hijrah-the-pursuit-of-identityfor-millennials-7de449d86ed0

Pahdepie, F. (2018, March 7). Siapakah Muslim milenial Indonesia itu. Geotimes. https://geotimes.id/kolom/agama/siapakah-muslim-milenial-indonesia-itu-i/

Pew Research Center. (2014). Millennials in adulthood: Detached from institutions, networked with friends. http://www.pewsocialtrends.org/2014/03/07/millennials-in-adulthood/

Prasanti, D., \& Indriani, S.S. (2019) Konstruksi makna hijrah bagi anggota komunitas let's hijrah dalam media sosial Line. Al-Izzah Jurnal Hasil-hasil Penelitian, 14(1), 106-119. http://dx.doi.org/10.31332/ai.v14i1.1253

Rogan, H. (2006). Jihadism online: A study of how al-Qaida and radical Islamist groups use the Internet for terrorist purposes. Kjeller: Forsvarets Forsknings Institutt. https://www.ffi.no/en/publications-archive/jihadism-online-a-study-of-how-al-qaidaand-radical-islamist-groups-use-the-internet-for-terrorist-purposes

Sands, K. Z. (2010). Muslims, identity and multimodal communication on the Internet. Contemporary Islam, 4(1), 139-155.

Statista. (2019). Leading countries based on number of Instagram users as of October 2019.

Suraya, \& Mulyana, A. (2020) Radicalism on teens as the effect of digital media usage. Jurnal Komunikasi: Malaysian Journal of Communication, 36(1), 76-89. https://doi.org/gk3c

Turner, B. S. (2007). Religious authority and the new media. Theory, Culture and Society, 24(2). https://doi.org/10.1177/0263276407075001

Van Dijk, T. A. (2001). Multidisciplinary CDA: A plea for diversity. In R. Wodak \& M. Meyer (Eds.), Methods of critical discourse analysis. London: Sage Publications.

Wildes, R. M. (2017). Millennials and religion: A new perspective. Huff Post. https://www.huffpost.com/entry/millennials-and-religion-a-new-perspective

Zahara, M.N., Wildan, D. \& Komariah, S. (2020) Gerakan Hijrah: Pencarian identitas untuk Muslim milenial di era digital. Indonesian Journal of Sociology, Education and Development, 2(1), 52-65. https://doi.org/10.52483/ijsed.v2i1.21 